\title{
LITTLE GULL IN SOUTHERN \\ MANITOBA AND ADJACENT \\ REGIONS, WITH NOTES ON \\ JUVENILE PLUMAGE
}

PETER TAYLOR, Box 597, Pinawa, Manitoba. R0E 1L0

Sightings of Little Gulls at Pinawa and Patricia Beach in September 1988 prompted me to review inland records of this species in Manitoba. Records in neighbouring regions are also briefly reviewed for evidence of any regional trends.

The Pinawa and Patricia Beach sightings involved first-year birds, the former still in juvenile plumage. This distinctive plumage, which is shown in the accompanying sketch, is not described in the most commonly used North American field guides, although it is discussed in more specialized identification books. ${ }^{7,11,12}$ It is therefore described here in detail, with emphasis on comparisons with Bonaparte's Gull and Sabine's Gull. The terminology used for plumage description follows Grant. ${ }^{7}$ The term "immature" is used when a distinction between juvenal and first-winter plumage has not been made.

\section{Description of 1988 Sightings}

At about 1400 h, 5 September 1988, I scanned a loose flock of about 40 Bonaparte's Gulls at the Pinawa sewage lagoons, and noticed a smaller, darkerbacked gull among them. I identified it as a juvenile Little Gull, and this was confirmed at about $1630 \mathrm{~h}$, by Gordon Grieef, George Holland, and Rudolf Koes. The gull was observed from as close as $35 \mathrm{~m}$ with $20 \mathrm{x}$ and $25 \mathrm{x}$ telescopes in fair light, and at somewhat longer ranges in excellent light. Koes obtained recognizable photographs. The gull was reported again the following day by Norman Cleveland, but could not be found after that. The Bonaparte's Gulls included both adults and immature, the latter in various stages of transition from juvenal to first-winter plumage. The following details distinguished the Little Gull from its companions.

The Little Gull was distinctly smaller than the Bonaparte's Gulls, its bill was shorter and dainty in comparison, and Koes commented on the small head and slender neck. The diffuse gray cap was darker and more extensive than on most immature Bonaparte's Gulls, but still separate from the eyes and blackish earspots. The forehead and lower napes were white. The lower hind-neck, mantle, scapulars and much of the folded wing were dark brownish gray; this dark tone extended to a small patch at the side of the upper breast, the remaining underparts being white. Narrow, pale feather margins, mainly on the scapulars, gave a distinctive scaly-backed appearance.

The Little Gull's markings and buoyant swimming posture gave the impression of a giant phalarope, almost as much as a small gull. The dark mantle and scapulars are the main features that distinguish juvenile Little Gulls from first-winter birds. ${ }^{7,11,12}$ Juvenile Bonaparte's Gulls are also quite dark- 


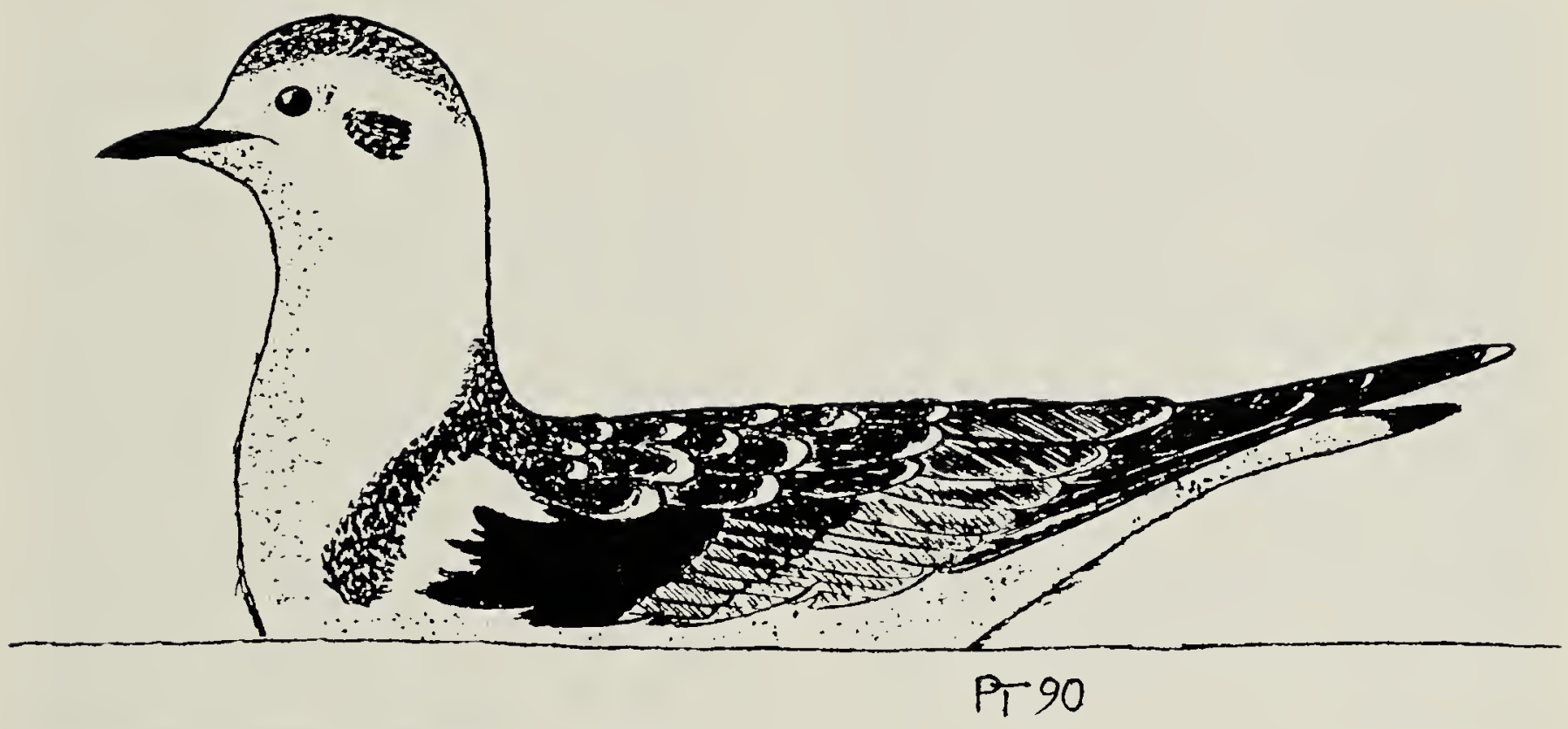

Peter Taylor

mantled, but are less strikingly marked on the scapulars than Little Gulls, and those moulting into first-winter plumage usually have mottled rather than scaly mantle and scapulars, because of the more irregular pattern of individual feathers. They also sometimes have some diffuse gray tones on and about the lower hind-neck, but not very dark.

When the Little Gull was swimming, its primaries appeared mainly black above, with some white inner vanes visible when the wings were extended or incompletely folded. In flight, the black carpal bars [dark bands on the leading upper surface of the inner wing] on the dorsal surface of the inner wing were bolder, and the primaries showed much more black, than on an immature Bonaparte's Gull. The portions of the upper wing coverts distal to the carpal bars were medium gray. The secondaries were whitish, and lacked the dark trailing edge typical of immature Bonaparte's Gulls. The entire undersurfaces of the wings were white. The black ter- minal band in the square-cut tail was wider on the central than the outer rectrices, which gave the illusion of a forked tail when viewed against a dark background. In immature Bonaparte's Gulls, the terminal band on the slightly rounded tail is uniformly narrow.

Both afloat and in the air, the Little Gull resembles a juvenile Sabine's Gull. The most distinguishing feature on the water, other than size, is that the Sabine's Gull has continuous graybrown feathering from the crown and ear-coverts down the neck to the mantle, with no intervening white area. Scaly markings on the back of a juvenile Sabine's Gull are less prominent than in a Little Gull. In flight, Sabine's Gull does not display a carpal bar, the entire inner forewing and the mantle being uniform in tone.

While swimming, the Pinawa Little Gull picked insects from the water surface much like the Bonaparte's Gulls, with somewhat livelier movements. It 
made a few brief flights, and on one occasion flew over the lagoon for about three minutes, often dropping momentarily to the water to pick up food. Both when swimming and flying, it seemed more buoyant than the Bonaparte's Gulls.

Less than two weeks after the Pinawa sighting, at about $1730 \mathrm{~h}$ on 17 September 1988, I saw a Little Gull at Patricia Beach, Lake Winnipeg, about $55 \mathrm{~km}$ west-northwest of Pinawa; there were no other observers. This bird was seen in good light, in company with Bonaparte's and Franklin's Gulls, but no closer than about $300 \mathrm{~m}$. Fewer details could therefore be seen, compared with the Pinawa bird, but the gull was positively identified by its small size and characteristic wing pattern, as described above. This wing pattern drew attention at a great distance when the bird was first seen. It was clearly an immature bird, but the stage of moult from juvenal to firstwinter plumage could not be determined. This bird was first seen flying across the lake, towards shore, and was later seen hawking insects with other gulls over a sheltered lagoon that adjoins the lake.

\section{Discussion}

The Little Gull's principal breeding range extends in patches from Siberia east to northern Europe.,11 A small breeding population exists in eastern North America, mainly in the Great Lakes region and along the coastal lowlands adjoining Hudson and James Bays in Ontario. ${ }^{1,3,5,11,29}$ It has been suggested that the latter region is the prime nesting area of this species in North America. ${ }^{3,29}$ This breeding region extends west to Churchill, Manitoba, where the Little Gull was first seen in 1970 and nesting was first observed in $1981 .^{19,21}$ A second nest was reported in 1987.6 Little Gulls have been recorded in very low numbers at Churchill every year since 1979, except perhaps 1988 (Koes, pers. comm.). However, they remain extremely rare elsewhere in the Prairie Provinces and in much of North America. ${ }^{1,4,5,15}$ The main North American wintering areas for this species are on the lower Great Lakes and along the Atlantic coast from Massachusetts to Virginia; winter movements in the Great Lakes region remain somewhat mysterious. ${ }^{1,28}$

The first inland report of a Little Gull in Manitoba involved a probable sighting of an immature bird in an unusual plumage at Lake Dauphin in late September 1970 by Martin K. McNicholl. ${ }^{18}$ Remarkably, the next four records all came from Grand Rapids, a locality infrequently visited by birders. Calvin W. Cuthbert saw an immature bird there, 28 September 1977; his detailed description is on file at the Manitoba Museum of Man and Nature in Winnipeg. ${ }^{24}$ An adult was seen and fully described by Alan Ryff and Harley Johnston at Grand Rapids, when they were en route to Churchill, 4 June $1983 .^{22}$ Finally, two sightings possibly involving the same bird were reported by John Christie (personal communication to Koes), 23 September 1986, and David Hatch, 15 October $19866^{10,13}$

The first accepted Little Gull in Saskatchewan was a lone territorial male collected near Lake Athabasca, 28 June $1962 .^{20}$ The location of this now bears the official name Little Gull Lake. Three subsequent Saskatchewan records were summarized by Belcher. ${ }^{2} \mathrm{~A}$ winterplumage adult was seen by many observers, and photographed by Frank Switzer at Regina, 20-26 April 1973.,26 Bernie Gollop observed an immature Little Gull at Dundurn (Blackstrap Lake) 6 October 1973.2.25 The most recently recorded Little Gull in Saskatchewan was apparently one seen by Wayne Harris at Deschambault Lake, 13 August $1975 .^{2}$

Alberta's first recorded Little Gulls were an adult and an immature at 
Namaka Lake, near Calgary, 22-29 September 1985. These were found by John Thompson and subsequently seen by several other observers, and photographed by Al Wiseley (Ross Dickson pers. comm.). ${ }^{9}$ An immature bird was found at Beaverhill Lake, 14 October 1986, by Richard Klauke and Pat Marklevitz, and seen again two days later by Terry Thormin and Dave Nadeau (Terry Thormin pers. comm.). ${ }^{10}$ Warren, Cam and Joy Finlay saw Alberta's fourth Little Gull, a winterplumaged adult near Cooking Lake, while they were running a breeding bird survey, 28 May 1988 (Warren Finlay, pers. comm.). ${ }^{27}$ In Minnesota, where the Little Gull was first reported in 1972, it is now a very rare but regular spring migrant (mainly near Duluth), and an accidental summer visitor and fall migrant. ${ }^{8,14}$ A nesting attempt was recorded in Jackson County, southwest Minnesota in $1986 .{ }^{14,23}$ Minnesota records include one immature Little Gull extremely close to Manitoba waters on Lake of the Woods, north of Warroad, 24 October $1984 .^{14,16}$ North Dakota's first Little Gull was an immature found by Ron E. Martin and Gordon B. Berkey, and photographed by David Lambeth at Garrison Dam, 27 November 1988; the species has apparently not yet been found in either South Dakota or Montana. ${ }^{17}$ A search of Ontario Region seasonal reports in American Birds did not turn up any inland records of Little Gulls in northwestern Ontario.

\section{Conclusions}

In summary, Little Gull is an extremely rare and irregular visitor to Alberta, Saskatchewan and southern Manitoba during migration seasons. The species is a rare breeder at Churchill, Manitoba, and has been observed once in the breeding season in northern Saskatchewan. It has been reported more frequently in fall (ten reports between August and October) than in spring (three reports between April and early June in the southern Prairie Provinces); this is the opposite situation from that reported for Minnesota. ${ }^{14}$ Immature (hatching-year) birds predominate in fall, whereas spring birds have all been adults, two of them still in winter plumage.

Little Gulls observed inland in Manitoba, or elsewhere in the Prairie Provinces, could have wandered from either the Hudson Bay or Great Lakes breeding populations. An origin outside North America is unlikely for a bird still in full juvenal plumage in Manitoba, but is possible for some of the birds discussed above. A further, tantalizing possibility is that other breeding areas remain to be found in or near the Prairie Provinces. Nero has suggested northern Saskatchewan as a possible nesting area. ${ }^{20}$ Perhaps Grand Rapids, Manitoba, would also be a good place to search for breeding evidence.

\section{Acknowledgements}

I am grateful to Ross Dickson, Sam Droege, Warren Finlay, Rudolf Koes, Robert Nero, Spencer Sealy, and Terry Thormin for information. Koes, Nero and Sealy also made helpful comments on a draft of this article.

1. AMERICAN ORNITHOLOGISTS' UNION. 1983. The A.O.U. checklist of North American birds. Sixth edition. American Ornithologists' Union. 877 pp.

2. BELCHER, M. 1980. Birds of Regina. Spec. Publ. 12. Sask. Nat. Hist. Soc., Regina. $151 \mathrm{pp}$.

3. CARPENTIER, A.G. 1986. Litule Gull nesting on the James Bay lowlands, Ontario. Ont. Birds 4:112-113.

4. DESANTE, D. and P. PYLE. 1986. Distributional checklist of North American birds. Vol. 1: United States and Canada. Artemesia Press, Lee Vining, CA. 442 pp.

5. GODFREY, W.E. 1986. The birds of Canada. Naul. Mus. Nat. Sci., Ottawa. 595 pp.

6. GOLLOP, B. 1987. The nesting season, June 1-July 31, 1987. Prairie Provinces Region. Am. Birds 4::1451-1453.

7. GRANT, P.J. 1982. Gulls: a guide to 
identification. Buteo Books, Vermilion, SD. 280 pp.

8. GREEN, J.C. and R.B. JANSSEN. 1975. Minnesota birds: where, when and how many. Univ. of Minnesota Press, Minneapolis. 217 pp.

9. HARRIS, W.C. 1986. The autumn migration, August 1-November 30, 1985. Prairie Provinces Region. Am. Birds 41:130-131.

10.HARRIS, W.C. 1986. The autumn migration, August 1-November 30, 1986. Prairie Provinces Region. Am. Birds 41:104-106.

11. HARRISON, P. 1985. Seabirds: an identification guide. Houghton Mifflin, Boston, MA. 448 pp.

12. HARRISON, P. 1987. A field guide to seabirds of the world. Stephen Greene Press, Lexington, MA. 317 pp.

13.HATCH, D.R.M. 1986. Variety of gulls confuses unwary. Chickadee Notes, Winnipeg Free Press, 1 November 1986.

14.JANSSEN, R.B. 1987. Birds in Minnesota. Univ. of Minnesota Press, Minneapolis. $352 \mathrm{pp}$.

15.JOHNSON, S.R. and W.J. ADAMS. 1977. The Little Gull (Larus minutus) in Arctic North America. Can. Field-Nat. 91:294-296.

16.JOHNSTON, A. 1984. A Little Gull on Lake of the Woods. The Loon 56:265.

17. LAMBETH, D.O. 1989. The autumn migration, August 1-November 30, 1988. Northern Great Plains Region. Am. Birds 40:130-131.

18. McNICHOLL, M.K. 1974. A probable
Little Gull record for southern Manitoba. Blue Jay 32:229-230.

19. McRAE, R.D. 1984. First nesting of the Little Guli in Manitoba. Am. Birds 38:368-369.

20.NERO, R.W. 1962. Birds of the Lake Athabasca region, Saskatchewan. Spec. Publ. 5, Sask. Nat. Hist. Soc., Regina. 143 pp.

21.PITTAWAY, R. and R.W. NERO. 1971. Recent bird notes of interest for Churchill, Manitoba. Blue Jay 29:60-63.

22.RYFF, A. and H. JOHNSTON. Churchill 1983. Unpublished trip report.

23. SCHLADWEILER, J. 1986. First state [Minnesota] nesting record for the Little Gull. The Loon 58:166-170.

24. SERR, E.M. 1978. The autumn migration, August 1-November 30, 1977. Northern Great Plains Region. Am. Birds 32: 220-223.

25.SHADICK, S. 1975. Highlights of Saskatoon bird observations, 1970-1974. Blue Jay 33:165-168.

26. SWTTZER, F. 1974. Little Gull visits Regina. Blue Jay 32:46-48.

27. THOMPSON, E. and S. DROEGE. 1989. BBS [Breeding Bird Survey] Monitor, Summer 1989, 6 pp.

28. WEIR, R.D. 1990. The winter season, December 11, 1989-February 28, 1990. Ontario Region. Am. Birds 44:262-266.

29. WESELOH, D.V. 1987. Little Gull. In Atlas of the breeding birds of Ontario (M.D. Cadman, P.F.J. Eagles and F.M. Helleiner, editors), Univ. of Waterloo Press, pp. 178-179.

Within three weeks of hatching, most young robins were within $0.1 \mathrm{mi}$ of their nests in a Massachusetts study. Within six weeks, most were still within $0.2 \mathrm{mi}$, and after eight weeks, a quarter of them were within $0.2 \mathrm{mi}$ and one-third had dispersed more than $0.5 \mathrm{mi}$. D.H Firth et al. 1969. Birdbanding 40:208-215. 